\title{
Recent advances in North American Pleistocene stratigraphy
}

\author{
Richard Foster Flin t \\ Yale University, New Haven, Connecticut, U.S.A. \\ Introduction
}

The Glacial Map of North America (FLINT and others 1945) assembled the essentials of what was known of North American Pleistocene stratigraphy as of 1942; the map data were amplified by FLINT (1947). Since the map appeared, a large volume of field work by many geologists and some other scientists has resulted in much new information. The discussion that follows is a review of some of the more important advances made during the last decade, but chiefly during the last five years.

\section{Extent of Nebraskandrift sheet}

The outermost drift in southeastern Nebraska, northeastern Kansas, and northern Missouri had been thought to be probably Nebraskan, the oldest of the four American drift sheets. This opinion was based partly on the inference that because much of that drift consists only of scattered boulders, the drift must be the residuum of a sheet of till from which the fines had been removed by erosion, and that such removal must have required a long time.

This argument loses force when it meets the fact that much of the drift in question cocupies a much-dissected belt of country with steep slopes, fringing the Missouri River, and some geologists have suspected that the outermost drift is not Nebraskan (First glacial) but Kansan (Second glacial). This view has been strengthened by test borings made in eastern Nebraska (E. C. REED, unpublished) and northeastern Kansas (Frye \& Walters 1950) where the outermost drift consists largely of continuous till. The borings show that the outer limit of the Nebraskan drift lies well inside the border of the Kansan drift, which overlaps and buries the Nebraskan drift border. By analogy it seems likely that the outermost drift in northern Missouri is likewise not Nebraskan but Kansan.

Borings through the Illinoian (Third glacial) drift in Illinois showed still earlier that in that State the Nebraskan drift sheet is less extensive than the Kansan, although both are buried beneath the Illinoian drift. Hence in a wide sector of the glaciated region the Nebraskan drift is less extensive than one or more younger drifts, and in no case is it the most extensive. In eastern United States where the outermost drift is variously Wisconsin (Fourth glacial), Illinoian, and Kansan, the Nebraskan drift has not been identified.

These data lead to the probability that the Nebraskan drift sheet is the least extensive of the drift sheets laid down by the Laurentide Ice Sheet, although in some districts, as in northeastern Iowa, it extends beyond the younger drifts. This probability takes on new interest in the light of the relations recently described (WIRTz \& Illies 1951) from the island of Sylt, off the west coast of Denmark. There are exposed coarse deposits of Scandinavian origin, possibly rafted on icebergs, and therefore suggesting a glacier that stopped short of Sylt. But the deposits lie in continuous stratigraphic sequence with fossil-bearing strata that are apparently uppermost Pliocene; hence, if glacial, they date from 
the First glaciation. A First glacial ice sheet that fell short of the limits reached by its successors is what seems to be recorded in the United States, and if the reasoning leading to this view is accepted, then the related climatic fluctuation was common to both America and Europe.

$\mathrm{Nonglacialsequencein} \mathrm{Kansas,} \mathrm{Nebraska,} \mathrm{and} \mathrm{South} \mathrm{Dakota}$

Recent extensive studies have clarified the Pleistocene nonglacial sequence in the territory stretching westward from the Missouri River. There the rivers flowing eastward from the Rocky Mountains across the Great Plains built a series of alluvial fills alternating with erosional excavations. Thanks to the fossil-vertebrate content of the fills, the widespread presence of a distinctive layer of volcanic ash, and the stratigraphic relations of fills to till sheets, correlation in considerable detail has been possible. The sequence recognized in Nebraska and South Dakota is shown in Table I. Details for Kansas have been published by Frye, Swineford \& Leonard (1948), and for Nebraska by Condra, REeD \& Gordon (1950). The South Dakota column is detailed in a report by Flint, now in course of publication by the United States Geological Society.

That the various sedimentary bodies differ conspicuously from each other as to grainsize is evident in Table I. However, no consistent correlation between these differences, and glacial- interglacial climatic fluctuations, exists. This suggests (although it does not prove) that grainsize changes are the result, at least in part, of factors other than climatic changes. They may be in part the result of broad crustal movements.

Table I - Correlation of Pleistocene alluvial deposits in Nebraska and South Dakota with the glacial sequence

\begin{tabular}{c|l}
\hline Glacial sequence & $\begin{array}{l}\text { Nonglacial sediments in } \\
\text { Nebraska and South Dakota }\end{array}$ \\
\hline \hline $\begin{array}{c}\text { Wisconsin } \\
\text { (Fourth glacial) }\end{array}$ & $\begin{array}{l}\text { Various glacial, alluvial and } \\
\text { loess deposits }\end{array}$ \\
\hline $\begin{array}{c}\text { Sangamon } \\
\text { (Third interglacial) }\end{array}$ & $\begin{array}{l}\text { (Deep weathering) } \\
\text { Illinoian } \\
\text { (Third glacial) }\end{array}$ \\
$\begin{array}{c}\text { Yarmouth } \\
\text { (Second interglacial) }\end{array}$ & $\begin{array}{l}\text { Loveland formation (valley } \\
\text { phase) (silt and clay) } \\
\text { Crete sand and gravel }\end{array}$ \\
\hline $\begin{array}{c}\text { Kansan } \\
\text { (Second glacial) }\end{array}$ & $\begin{array}{l}\text { Sappa silt and clay } \\
\text { (including Pearlette volcanic } \\
\text { ash horizon) }\end{array}$ \\
\hline $\begin{array}{c}\text { Aftonian } \\
\text { (First interglacial) }\end{array}$ & $\begin{array}{l}\text { Grand Island sand and gravel } \\
\text { Red Cloud sand and gravel }\end{array}$ \\
\hline $\begin{array}{c}\text { Nebraskan } \\
\text { (First glacial) }\end{array}$ & $\begin{array}{l}\text { Fullerton } \\
\text { silt and clay }\end{array}$ \\
\hline
\end{tabular}

An interesting fact emerging from study of the fossils in the alluvial fills in Nebraska is that the most conspicuous faunal change occurred at the time of maximum extent of the Kansan ice sheet. This is not primarily a change from glacial to nonglacial, or vice-versa, but consists simply of strikingly new ele- 
ments in the regional mammal-fauna. (See faunal chart in Condra, ReEd \& Gordon 1950). The underlying cause of the change is not apparent.

Extent and stratigraphy of Illinoian deposits

When the Glacial Map of North America (FLINT and others 1945) was published, Illinoian drift had not been recognized west of the Mississippi River except in extreme southeastern Iowa.

Because of this, some geologists believed that in Illinoain time the ice sheet was confined to the northeastern part of North America, and deduced climatic and meteorologic consequences that seemed to be inconsistent with the probabilities. Recently, however, it has been shown to be present in South Dakota (Warren, 1949) and Minnesota (R. V. RuHE, unpublished). In South Dakota the Illinoian drift border is everywhere buried beneath the more extensive Wisconsin drift; this fact delayed recognition of the presence of the older drift sheet. It now seems likely, therefore, that the Illinoian drift sheet continues northwestward, with an areal extent similar to that of the Wisconsin drift. If so, the climatic anomalies implicit in earlier, erroneous concepts of its extent cisappear , and the distribution of the Illinoian in America becomes more nearly comparable with the distribution of the Saale drift in Europe.

In this connection it has come to be recognized that the extensive Loveland loess sheet is not Sangamon (Third interglacial) as was formerly supposed, but Illinoian. The areal distribution of the Loveland loess is consistent with the newly recognized, extended distribution of the Illinoian drift. There can be little doubt as to the genetic relationship of that loess to that drift.

The discovery of buried weathering profiles within the Loveland loess in Nebraska suggests that there were two or more episodes of loess sedimentation, well separated in time. As bursts of loess deposition within the Wisconsin (Fourth Glacial) sequence are correlated rather generally with glacial maxima, the implication of repeated expansions of the Illinoian ice sheet is plain. If in fact there were two such expansions, the Illinoian stratigraphy would resemble that of Germany according to the present view of WoldstedT (1950, cf.p. 256, 302), with the Warthe drift sheet interpreted as the product of a second expansion of the ice sheet during the Saale glacial age.

It is worth noting also that the Illinoian ice sheet, rather than an earlier one, was responsible for the major drainage rearrangement that created the present Missouri River in North Dakota and South Dakota. The upper Missouri, in preIllinoian time, flowed east and north to the region of Hudson Bay; the Illinoian blockade and diversion, which has become permanent, has shifted the continental divide between the Arctic Sea watershed and the Gulf of Mexico watershed, far to the south of its former position.

\section{Stratigraphy of the Wisconsin stage}

During the past few years great advances have been made in our understanding of the Wisconsin drift. When the Glacial Map of North America was published the Wisconsin drift between the Mississippi River and the Rocky Mountains was very imperfectly known. Only two Wisconsin substages had been identified, and these were tentatively regarded as Iowan and Mankato, respectively. Again this led to deductions concerning the extent of the Wisconsin ice sheet and the climatic conditions controlling it, which, it is now evident, were erroneous. Coordinated mapping of the Wisconsin drift by several geologists in South Dakota, western Iowa, southwestern Minnesota, and eastern Nebraska 
has established the presence, in that combined region, of four Wisconsin substages, the Iowan, Tazewell, Cary, and Mankato substages identified elsewhere on the Glacial Map of North America. The areal relations of these four substages are nearly identical in the two great glacial lobes--the Des Moines lobe in Iowa and Minnesota and the James lobe in South Dakota, indicating that the ice sheet responded in the same way to climatic fluctuations that affected both lobes simultaneously.

These relationships are described for Iowa by R. V. RuHE and for South Dakota by R. F. Flint, in discussions now in course of publication. Subdivision of the Wisconsin drift is also in progress in North Dakota and Montana, but owing to thinness of the drift sheets, erosional dissection, and distance from the region in which the stratigraphy is best known, correlation is still somewhat uncertain.

In South Dakota and Iowa the four Wisconsin substages are separated from each other by sheets of loess. The loess between the Iowan and Tazewell drifts is, however, very thin and wholly unaltered; hence it is inferred that the IowanTazewell interval was probably very short and witnessed only moderate withdrawal of the ice sheet from the region. As both the Tazewell drift and its overburden of loess are much thicker than the Iowan drift and loess, the Iowan glacial maximum can be thought of as a relatively short-lived advance pulse of a longer-lived though less extensive maximum of Tazewell date.

At many places west of the Mississippi River the Tazewell-Cary interval is marked by a zone of moderate weathering and soil development (although with a far less mature weathering profile than that produced during the Sangamon interglacial age). In contrast, the Cary-Mankato interval lacks the weathering zone, although in the region of subhumid climate it is characterized by a Chernozem soil. From these facts it seems likely that there is only one substantial break within the Wisconsin sequence, and that it intervened between the Tazewell and the Cary glacial sub-ages. During this break the ice-sheet margin may have withdrawn altogether from north-central United States. As the IowanTazewell interval and the Cary-Mankato interval indicate a less marked change in conditions, the fourfold Wisconsin stratigraphic sequence may be viewed best, perhaps, as consisting of two pairs of two glacial maxima.

This view is supported and amplified by the results of recent study of loess stratigraphy in Illinois, Kansas, and Nebraska, outside the limits of the Wisconsin drift. In Illinois (Leighton \& Willman 1950) the section is fivefold. The four upper units are correlated with Wisconsin glacial substages through tracing into the drift region. Respectively they underlie the Tazewell till, overlie the Tazewell till, overlie Cary outwash, and (as sandy deposits) overlie Mankato outwash, and hence are Iowan, Tazewell, Cary, and Mankato. The fifth and lowest unit overlies the Sangamon (Third interglacial) zone of weathering, underlies the Iowan loess (from which it is separated by a zone of slight leaching), and is areally related to outwash valley trains of major river valleys. These facts imply that this lowest Wisconsin loess - named Farmdale loess - represents a brief pre-Iowan glacial expansion that failed to reach as far south, in Illinois, as the Tazewell ice sheet. On this basis the first group of glacial maxima should be thought of not as a pair but a trio.

In Kansas (Leonard 1951; Frye \& Leonard 1951) the section is fourfold, and consists of three zones, distinguished principally on an invertebrate-faunal basis, separated from a fourth, overlying zone by a pronounced horizon of 


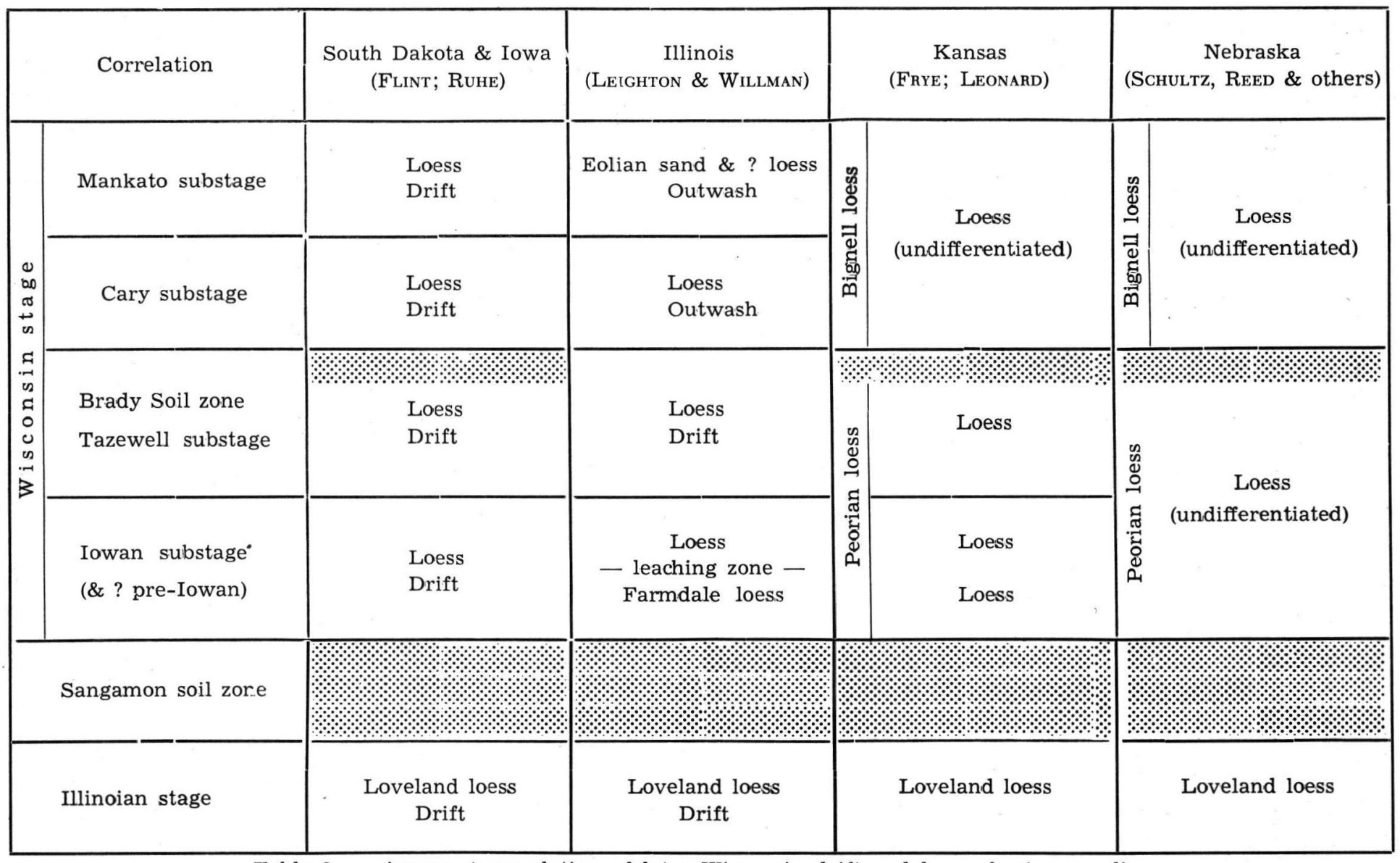

Table 2. - Apparent correlation of later Wisconsin drift and loess sheets according

to information available at the end of 1951 
weathering and soil development. There is reason to believe that the intervening horizon, termed $\mathrm{Brady}$ soil, represents the Tazewell-Cary interval. The lowest of the five zones in the loess is believed to correlate with the Farmdale loess in Illinois. However, unlike that loess it is not separated from the overlying zone by a leaching horizon, and this may reflect the fact that the Kansas sections are more distant from the border of the Wisconsin drift than are the sections in Illinois. The four overlying zones are believed to be respectively, Iowan, Iowan-Tazewell transition, Tazewell, and Cary-Mankato. The fact that in Kansas the Iowan loess is transitional into the Tazewell loess supplements the evidence in Iowa and South Dakota that the Iowan-Tazewell interval was brief and was not characterized by great shrinkage of the ice sheet. The fact that the Cary and Mankato loess sheets seem to form a single unit in Kansas probably reflects the considerable distance between Kansas and the outer limits of the Cary and Mankato drift sheets, a minimum of 200 miles traced along outwash routes.

In Nebraska (cf. Schultz, Lueninghoener \& Frankforter 1951) the Wisconsin loess is subdivided into a lower part (Iowan and Tazewell) and an upper part (Cary and Mankato), the two parts separated by the Brady soil zone. Detailed examination of the invertebrate faunas very likely will lead to a more complete subdivision of the section, as has been done in Kansas.

The correlations mentioned above are shown in Table 2. According to them the Wisconsin stage is subdivided by the Brady soil into an upper pair and a lower pair of substages; if the fluctuation implied by the leaching of the Farmdale loess proves to be important, then the lower pair would become threefold, at least in Illinois.

A weathering zone at the stratigraphic position of the Brady soil - that is, between the Tazewell and Cary drift sheets - has been identified in Indiana (WAyne \& Thornbury 1951, p. 16).

That the ice-sheet margin, during the Tazewell-Cary interval, stood farther north than Aylmer, Ontario, is suggested by widespread lacustrine deposits, apparently dating from that interval, in the Aylmer district (A. Dreimanis, unpublished).

Undoubtedly the subdivisions are determined by climatic fluctuation, and speculation as to correlation with the Fourth Glacial sequence in Europe is unavoidable. The question arises whether the Rosenthaler Randlage (WoLDSTEDT 1950, p. 213) and the pre-Brandenburg Weichsel drift in Jutland (K. MiLTHERs, unpublished), representing apparently an early Fourth Glacial expansion of the Scandinavian Ice Sheet, may be the correlative of the ice advance suggested by the Farmdale loess, or wheter it may represent the Iowan advance - or perhaps both.

The question arises also whether in central Europe the weathering horizon that separates the Younger Loess I from the Younger Loess II - the horizon representing the so-called „Aurignacian interval“ (cf. Woldsted 1950, p. 365) is the correlative of the Brady soil zone. No fact presently known seems to stand in the way of such a correlation.

In South Dakota and Iowa the Iowan drift sheet is the most extensive of the Wisconsin (Fourth Glacial) substages. In contrast, in Illinois, Indiana, and Ohio the most extensive Wisconsin substage is the Tazewell. That the Iowan is present, at least in Illinois, is indicated by the presence of the Iowan loess; presumably the Iowan drift border passes beneath the Tazewell drift near the Mississippi River and continues eastward beneath the younger drifts. Regional 
variations in the extents of successive ice sheets seem to find logical explanation in the atmospheric circulation pattern deduced from analogy with present-day short-period fluctuations (cf. FLINT \& DoRSEY 1945); specifically the deduced shift from a low-index pattern in Iowan time to a high-index in Tazewell time is consistent with the presently known borders of the two respective drift sheets.

In this connection it is interesting that the Wisconsin drift of the Green River lobe in northwestern Illinois, long of debatable correlation, has been established as Tazewell. Also this drift is more extensive than is shown on the Glacial Map of North America, as it extends west to the bluffs of the Mississippi River trench in Iowa (Leighton \& Shaffer 1949).

In Indiana and Ohio the Tazewell and Cary drift sheets have been identified stratigraphically and the approximate positions of their borders determined. In Indiana, as already noted, the interval between them is represented by a zone of weathering. In Ohio this interval is represented by fossil logs of forest trees incorporated in Cary till (R. P. Goldthwart, unpublished; cf. Flint \& Deevey 1951, p. 286); in western Pennsylvania (Schopf \& Cross 1947; Flint \& Deevey 1951, p. 286) it is represented probably by peat.

It has been shown by Bretz (1951, p. 422) that the Port Huron endmoraine in Michigan, formerly believed to represent the outermost position of the icesheet margin during the Mankato substage, actually was built during the later part of Cary time, and that the Mankato maximum is represented by the Manistee endmoraine, which lies farther north. This discovery brings the stratigraphic sequences on the two sides of Lake Michigan into agreement

The Mankato maximum was separated from the earlier, Cary maximum by a pronounced shrinkage of the ice sheet. The ecology of peat accumulated near Two Creeks, Wisconsin (see references in Flint \& DeEvey 1951, p. 262) during the shrinkage, and evidence of a pronounced lowering of the water in the Lake Michigan basin as it found a new outlet through the Strait of Mackinac (Bretz 1951) indicate that the contemporaneous glacier margin stood north of the existing Great Lakes. Radiocarbon determinatinos on the Two Creeks peat date the peat at $11,400 \pm 350$ years, and from the radiocarbon dates cf other materials it is inferred that Lake Algonquin III was in existence around 5,000 years ago and that the early Nipissing Great Lakes were in existence around 3,500 years ago (Flint \& DeEver 1951, p. 283-285). All these dates are rather surprisingly small; probably they indicate that the rate of melting of the Laurentide Ice Sheet accelerated during the later part of the Wisconsin Glacial age.

Evidence has continued to accumulate that two successive „postglacial“ seas occupied the St. Lawrence lowland. The first carried a dominantly cold fauna; the second seems to record temperate conditions. There are indications that an episode of expanded glaciers followed the two marine incursions, and that in the St. Lawrence valley upstream from Quebec City the glacier ice was not the Laurentide Ice Sheet but an ice cap centered in the Appalachian region south of the river (cf. OsBorne 1951).

The latter fact is typical of events in the highland region of northeastern North America, in which many local ice caps and cirque glaciers survived the general ice-sheet deglaciation (FLINT 1951), thus greatly complicating the lateWisconsin sequence of events.

A study by DeEvey (1951) has shown that pollen sequences in Aroostook County, Maine, are remarkably similar to those in northern Europe, with an Alleröd-like zone succeeded by evidence of colder climate. DeEvey (1951, p. 197) 
suggested the „remote possibility“ that the Alleröd-like zone represents the Cary-Mankato interval, and that although the Mankato glaciation influenced the vegetation in Maine, Mankato ice did not reach that vicinity. Should this possibility be substantiated by further pollen studies, it would aid in fixing the still-unknown position of the Mankato glacial limit in the New England region.

It has been known for several years that two drift sheets of Wisconsin age are present in southeastern New England. This knowledge has been advanced by a recent detailed study (Judson 1949) of the Boston area, in which a young till and outwash are found in several places to overlie an older sequence of till and marine sediments, the older sequence having been oxidized and eroded before the advent of the younger.

Within the northeastern region mention should be made also of the valuable attempt by LEIGHLY (1949) to reconstruct the glacial-age climatic conditions along the 49th parallel of latitude from the Rocky Mountains to Newfoundland, and the application by Hare (1951) of the study of present-day snowfall to the growth of the Laurentide Ice Sheet. Both papers have advanced our knowledge of the meteorologic circumstances of ice-sheet development.

\section{Cordilleran region}

Pleistocene studies in the Cordilleran region have been fewer than in the region covered by the ice sheet, but progress has been made. Detailed work in the Wind River Mountains in Wyoming and the La Sal Mountains in Utah have revealed a fourfold sequence of Wisconsin glacial deposits which, after further study, it should be possible to correlate with the Wisconsin stratigraphy of the Mississippi Valley region (G. M. Richmond, unpublished).

\section{Frozen-ground phenomena}

The study of frozen-ground phenomena associated with the glacial stages is less advanced in North America than it is in Europe. Publications thus far consist mainly of local descriptions; little attempt at regional synthesis has been made. One of the more extensive studies is that of Peltien (1949) which describes flow earth in the valley of the Susquehanna River and its tributaries in Pennsylvania, and attempts to date this material with respect to bodies of glacial outwash with which it is in contact.

\section{Conclusion}

The foregoing account attempts to summarize briefly the chief advances made during the past few years in the stratigraphy of the North American glacial deposits. The coverage is very incomplete, because a space limitation forbade mention of a number of valuable papers in this general field. However, the reader interested in further study will find that the bibliographies contained in the papers listed below provide an extensive and up-to-date reading list.

\section{References}

Bretz, J. Harlen (1951) The stages of Lake Chicago: their causes and correlations. Am. Jour. Sci. 249, p. 401-429.

Condra, G. E., Reed, E. C. \& Gordon, E. D. (1950) Correlation of the Pleistocene deposits of Nebraska [Originally published 1947; revised by G. E. ConDrA \& E. C. REED 1950]. - Nebraska Geol. Survey, Bull. 15A, 74 pages.

Deever, E, S., Jr. (1951) Late-glacial and postglacial pollen diagrams from Maine. Am. Jour. Sci. 249, p. 177-207. 
Flint, R. F. \& Dorsey, H. G., Jr. (1945) Iowan and Tazewell drifts and the North American Ice Sheet. - Am. Jour. Sci. 243, p. 627-636.

- and others (1945) Glacial Map of North America. - Geol. Soc. Am., Spec. Paper 60, Part I - Glac. map (in color); Part II - Explanatory notes, 37 pages.

FurNT, R. F. (1947) Glacial geology and the Pleistocene epoch. New York: John Wiley \& Sons, 589 pages. - (1951) Highland centers of former glacial outflow in northeastern North America. - Bull. Geol. Soc. Am. 62, p. 21-38.

Flint, R. F. \& DeEver, E. S., Jr., (1951) Radiocarbon dating of late-Pleistocene events. Am. Jour. Sci, 249, p. 257-300.

Frye, J. C., Swineford, Ada \& Leonard, A. B. (1948) Correlation of Pleistocene deposits of the central Great Plains with the glacial section. - Jour. Geol. 56, p. 501-525.

- \& Walters, K. L. (1950) Subsurface reconnaissance of glacial deposits in northeastern Kansas. - Kansas Geol. Survey, Bull. 86, pt. 6, p. 141-158.

- \& Leonard, A. B. (1951) Stratigraphy of the late Pleistocene loesses of Kansas. - Jour. Geol. 59, p. 287-305.

HAre, F. K. (1951) The present day snowfall of Labrador-Ungava. - Am. Jour. Sci. 249, p. $654-670$.

Judson, Sheldon (1949) The Pleistocene stratigraphy of Boston, Massachusetts and its relation to the Boylston Fishweir. - p. 7-48 in: The Boylston Street Fishweir II. A study of the geology, palaeobotany, and biology of a site on Stuart Street in the Back Bay district of Boston, Massachusetts, by E. S. BARGHOoRN, and others. - Papers of the Robert S. Peabody Foundation for Archaeology 4, no. 1.

LEIGHLY, John (1949) On continentality and glaciation. - Geogr. Annaler, p. 133-145.

Leighton, M. M. \& Shaffer, P. R. (1949) Newly discovered extension of the Labradorean ice sheet into eastern Iowa during the Tazewell substage of the Wisconsin stage [Abstr.]. - Bull. Geol. Soc. Am. 60, p. 1904.

- \& Willman, H. B. (1950) Loess formations of the Mississippi Valley. - Jour. Geol. 58, p. 599-623.

Leonard, A. B. (1951) Stratigraphic zonation of the Peoria loess in Kansas. - Jour. Geol. 59, p. 323-332.

Osborne, F. F. (1951) Parc des Laurentides ice cap and the Quebec sea. - Naturaliste Canadien 78, p. 221-251.

Peltier, L. C. (1949) Pleistocene terraces of the Susquehanna River, Pennsylvania. Pennsylvania Geol. Survey, 4th ser., Bull. G23, 158 pages.

Schopf, J. M. \& Cross, A. T. (1947) A glacial age peat deposit near Pittsburgh. - Am. Jour. Sci. 245, p. 421-433.

Schultz, C. B., Lueninghoener, G. C. \& Frankforter, W. D, (1951) A graphic resumé of the Pleistocene of Nebraska (with notes on the fossil mammalian remains). Bull. Univ. Nebraska State Museum 3, no, 6, 41 pages.

Warren, C. R. (1949) Probable Illinoian age of part of the Missouri River [Abstr.]. Bull. Geol. Soc. Am. 60, p. 1926.

WAYNe, W. J. \& ThornburY, W. D. (1951) Glacial geology of Wabash County, Indiana. Bull. Indiana Geol. Survey 5, $39 \mathrm{p}$.

Wirtz, Daniel \& Illies, Henning (1951) Lower Pleistocene stratigraphy and the PlioPleistocene boundary in northwestern Germany. - Jour. Geol. 59, p. 463-471.

Woldstedt, Paul (1950) Nonddeutschland und angrenzende Gebiete im Eiszeitalter. Stuttgart, K. F. Koehler, 464 pages.

Ms. eingeg. 13. 5. 52

Anschr. d. Verf.: Prof. R. F. Flint, Yale Univ., Dep. of Geology, New Haven, Conn., USA. 